\title{
Evaluation of the health of seeds and sprouts intended for human consumption
}

\author{
Ocena zdrowotności nasion oraz uzyskiwanych z nich \\ kiełków przeznaczonych do konsumpcji
}

\author{
Lidia Irzykowska*, Małgorzata Kononowicz
}

\begin{abstract}
Summary
Nowadays, people are searching for natural sources of valuable products, which can supplement and improve food value. Healthy diet is often enriched by consumption of sprouts with high nutrient content originating from different plant species. The aim of this study was to evaluate the health of broccoli, sunflower, radish and mung beans seeds and sprouts obtained from these plant species destined for consumption. Blotter and agar test were used to evaluate presence of microorganisms in seeds and sprouts. Sunflower plants showed the smallest germination capacity and energy - maximum $80 \%$ while radish seeds sprouted at $85 \%$ after 6 days. Broccoli and mung beans germinated evenly at the range of $99 \%$. Sunflower seeds chose for sprout production were the most infected by various species of fungi, including the potential toxic, such as Penicillium spp. (38\%), Fusarium spp. (8\%), Alternaria spp. (4\%). It has been observed that the seeds of broccoli, radish and mung beans were also infected by the mentioned above pathogens. Evaluation of fungus colonization on commercially available sprouts showed that the largest infection occurred on sunflower sprouts. The following species were identified Mucor - 30\%, Alternaria - 26\%, Trichoderma - 12\%, Penicillium - 10\%, Fusarium - 3\%. The infection of these species didn't exceed $8 \%$ on other studied plants.
\end{abstract}

Key words: germs; seed health; toxigenic fungi; mycotoxins

\section{Streszczenie}

Współcześnie, poszukuje się naturalnych źródeł cennych substancji, którymi można uzupełniać i podnosić funkcjonalność żywności. Dieta dbającego o zdrowie człowieka często jest wzbogacana spożyciem bogatych w cenne związki kiełków z nasion różnych gatunków roślin. Celem badań była ocena zdrowotności nasion brokuła, słonecznika, rzodkwi i fasoli mung oraz uzyskiwanych z nich kiełków przeznaczonych do konsumpcji. Stan mikrobiologiczny nasion i kiełków oceniono wykorzystując test bibułowy i agarowy. Spośród badanych gatunków najmniejszą zdolność i energię kiełkowania wykazał słonecznik - maksymalnie 80\%. Rzodkiew po 6 dniach skiełkowała w $85 \%$. Brokuł i fasola mung kiełkowały równomiernie w granicach $99 \%$. Spośród przebadanych nasion przeznaczonych na kiełki, nasiona słonecznika były w największym stopniu zasiedlone przez różne gatunki grzybów, w tym potencjalnie toksynotwórczych, takich jak Penicillium spp. (38\%), Fusarium spp. (8\%), Alternaria spp. (4\%). Zaobserwowano, że nasiona brokuła, rzodkwi i fasoli mung także były porażone przez ww. patogeny. Ocena zasiedlenia przez grzyby dostępnych w handlu kiełków wykazała największe porażenie w przypadku słonecznika. Na kiełkach zidentyfikowano grzyby z rodzaju Mucor - 30\%, Alternaria - 26\%, Trichoderma - 12\%, Penicillium - 10\%, Fusarium - 3\%. U pozostałych gatunków zasiedlenie wymienionymi grzybami nie przekroczyło $8 \%$.

Słowa kluczowe: kiełki; zdrowotność nasion; toksynotwórcze grzyby; mykotoksyny

\footnotetext{
Uniwersytet Przyrodniczy w Poznaniu Katedra Fitopatologii i Nasiennictwa Dąbrowskiego 159, 60-594 Poznań

*corresponding author: lidia.irzykowska@up.poznan.pl
} 


\section{Wstęp / Introduction}

Współcześnie, zapotrzebowanie na pełnowartościową dietę jest bardzo duże. Poszukuje się naturalnych źródeł cennych substancji, którymi można uzupełniać i podnosić funkcjonalność żywności. Kiełki stają się cennym źródłem wartościowych składników odżywczych w okresie zimowym, kiedy świeże warzywa i owoce są niedostępne, a związki obecne w kiełkach sprzyjają utrzymaniu odporności organizmu. Kiełki są bogatym źródłem substancji, takich jak: aminokwasy, witaminy, mikroelementy, błonnik i nienasycone kwasy tłuszczowe, a także witamin: A, B, C, $\mathrm{E}, \mathrm{H}$ oraz zawierają pierwiastki, takie jak: cynk, magnez, żelazo, potas, siarka, wapń, lit i chrom (Gawlik-Dziki i Kowalczyk 2007; Lewicki 2010; Świeca i wsp. 2012). Poprzez odpowiednio dobrane procesy technologiczne skład chemiczny kiełków może być modyfikowany, czyniąc je istotnym elementem tzw. żywności funkcjonalnej.

O korzyściach dla zdrowia człowieka płynących ze spożycia kiełków można mówić jedynie wtedy, kiedy kiełki pozyskano w prawidłowy sposób $\mathrm{z}$ wolnych od patogenów nasion. Niestety, nasiona przeznaczone na kiełki mogą być zasiedlone przez niepożądane grzyby, co drastycznie obniża ich jakość. Szczególnie niekorzystne jest występowanie grzybów biosyntetyzujących mykotoksyny, które na organizm człowieka mogą wpływać nefrotoksycznie, hepatotoksycznie, neurotoksycznie lub immunosupresyjnie (Laemmlen 2001; Ito i wsp. 2004; Ogórek i wsp. 2011).

Celem badań była ocena zdrowotności i równomierności kiełkowania nasion słonecznika, rzodkwi, brokuła i fasoli mung przeznaczonych na kiełki oraz dostępnych w handlu kiełków ww. gatunków.

\section{Materiały i metody I Materials and methods}

Materiał do badań stanowiły komercyjnie dostępne nasiona wybranych gatunków roślin, przeznaczone na świeże kiełki. Analizie poddano nasiona brokuła (Brassica oleracea var. italica L.), słonecznika (Helianthus annus L.), rzodkwi (Raphanus sativus L.) i fasoli mung (Vigna radiata L.). Ponadto analizowano gotowe, dostępne w handlu kiełki ww. nasion, przeznaczone do bezpośredniej konsumpcji.
Ocenę kiełkowania nasion przeprowadzono posługując się testem agarowym rekomendowanym przez ISTA (2003). Po sto nasion każdego z analizowanych gatunków wykładano na płytki Petriego ze sterylną bibułą filtracyjną, nasączoną wodą destylowaną $(20$ płytek $\times 5$ nasion/gatunek) w celu oceny energii i zdolności kiełkowania nasion. Nasiona inkubowano przez 6 dni w temperaturze $20^{\circ} \mathrm{C}$. Po 3 dniach określono energię kiełkowania, natomiast po 6 dniach zdolność kiełkowania nasion. Wyniki zweryfikowano w programie STATISTICA v. 12, z wykorzystaniem jednoczynnikowej analizy wariancji. Do określenia różnic między kombinacjami zastosowano test Duncana, na poziomie istotności $\alpha=0,05$.

Do oceny zasiedlenia nasion przez grzyby zastosowano test agarowy zgodnie $\mathrm{z}$ metodyką opisaną przez Duczmala (1993). Ocenę zasiedlenia nasion przez grzyby przeprowadzono wykładając po 100 nasion każdego gatunku na pożywkę agarowo-glukozowo-ziemniaczaną (PDA - Potato Dextrose Agar, Sigma). Płytki z nasionami inkubowano w temperaturze pokojowej przez 10 dni. Wyrastające $\mathrm{z}$ zainfekowanych nasion kultury grzybów pasażowano na czyste podłoże PDA w celu uzyskania czystych kultur.

Ocenę zdrowotności gotowych kiełków przeprowadzono posługując się testem agarowym. Na pożywkę agarowo-glukozowo-ziemniaczaną wyłożono losowo po 20 kiełków każdego gatunku. Każdy z nich został podzielony na 5 fragmentów. $\mathrm{Z}$ wyrastających $\mathrm{z}$ fragmentów kiełków strzępek grzybni wyprowadzano czyste kultury.

Identyfikacji grzybów występujących zarówno na nasionach, jak i na kiełkach dokonano poprzez mikroskopową ocenę ich cech morfologicznych.

\section{Wyniki i dyskusja / Results and discussion}

W teście bibułowym, po 3 dniach obserwacji stwierdzono, że największą energią kiełkowania cechowały się nasiona fasoli mung $\mathrm{i}$ brokuła, natomiast najniższą energię kiełkowania odnotowano $\mathrm{w}$ przypadku nasion słonecznika. Tendencja ta została zachowana także po 6 dniach inkubacji, kiedy największą zdolność kiełkowania ponownie stwierdzono w przypadku nasion fasoli mung i brokuła (tab. 1).

Tabela 1. Energia i zdolność kiełkowania nasion fasoli mung, słonecznika, brokuła i rzodkwi

Table 1. Germination energy and capacity of mung bean, sunflower, broccoli and radish seeds

\begin{tabular}{l|c|c}
\hline \multirow{2}{*}{$\begin{array}{l}\text { Gatunek - Species } \\
\text { Brokuł - Broccoli - Brassica oleracea L. }\end{array}$} & $\begin{array}{c}\text { Energia kiełkowania } \\
\text { Germination energy } \\
{[\%]}\end{array}$ & $\begin{array}{c}\text { Zdolność kiełkowania } \\
\text { Germination capacity } \\
{[\%]}\end{array}$ \\
\cline { 2 - 3 } & $\begin{array}{c}\text { po 3 dniach } \\
\text { after 3 days } \\
\text { after } 6 \text { days }\end{array}$ & $99 \mathrm{~b}$ \\
\hline Słonecznik - Sunflower - Helianthus annus L. & $98 \mathrm{~b}$ & $80 \mathrm{a}$ \\
\hline Rzodkiew - Radish - Raphanus L. & $87 \mathrm{a}$ & 85 ab \\
\hline Fasola mung - Mung beans - Vigna radiata L. & $99 \mathrm{~b}$ & $100 \mathrm{~b}$ \\
\hline
\end{tabular}

Wartości oznaczone tymi samymi literami nie różnią się istotnie według testu Duncana, $\alpha=0,05$

Means followed by the same letters are not significantly different according to the Duncan's test at the level $\alpha=0.05$ 
W teście agarowym oceniono zdrowotność nasion oraz kiełków. W badanych próbach nasion zasiedlenie przez grzyby z rodzaju Penicillium spp. było największe w przypadku fasoli mung i wyniosło $41 \%$ (tab. 2). Gatunki z rodzaju Fusarium zasiedlały nasiona słonecznika, brokuła i rzodkwi w niewielkim stopniu, gdyż odsetek porażonych nasion nie przekraczał $3 \%$, natomiast w przypadku fasoli mung $17 \%$ nasion było zasiedlone przez Fusarium spp. (tab. 2).

Patogeny z rodzaju Trichoderma wystąpiły na kiełkach wszystkich badanych gatunków roślin. Największe porażenie, na poziomie $12 \%$, zaobserwowano na kiełkach słonecznika (tab. 3). Spośród wszystkich zidentyfikowanych na kiełkach słonecznika patogenów dominowały grzyby z rodzaju Alternaria, które zasiedlały 26\% kiełków. Zasiedlenie przez grzyby należące do rodzaju Mucor zaobserwowano zarówno na nasionach, jak i kiełkach, przy czym w największym nasileniu, sięgającym odpowiednio 19 i 30\% grzyby te wystąpiły na nasionach (tab. 2) i kiełkach (tab. 3) słonecznika.

Ponadto na nasionach i kiełkach stwierdzono śladowe występowanie innych grzybów, między innymi 5\% nasion słonecznika było zasiedlone przez Ulocladium atrum, gatunek Aspergillus niger występował na nasionach fasoli mung, a Colletotrichum gleosporioides na kiełkach rzodkwi (tab. 2, 3).

W niniejszej pracy analizowano zdrowotność nasion słonecznika, fasoli mung, rzodkwi i brokuła przeznaczonych na kiełki oraz oceniano zasiedlenie gotowych, dostępnych w handlu kiełków ww. gatunków. Dodatkowo oceniono równomierność kiełkowania nasion.

Według informacji na etykiecie nasiona badanych roślin miały równomiernie kiełkować i po 3-4 dniach (rzodkiew, fasola mung), 5-7 dniach (brokuł) lub 4-5 dniach (słonecznik) kiełki powinny być gotowe do spożycia. Badania wykazały, że nasiona brokuła i fasoli mung kiełkowały najszybciej i były gotowe do spożycia już po 3 dniach. Natomiast nasiona słonecznika i rzodkwi odznaczały się niższą zdolnością kiełkowania i nawet po 6 dniach nie przekraczała ona $85 \%$.

W przeprowadzonych badaniach stwierdzono, że zarówno nasiona, jak i kiełki używane do wzbogacenia diety były zasiedlone przez różne gatunki grzybów m.in. z rodzajów: Alternaria, Fusarium, Trichoderma, Mucor i Penicillium. Najwyższą czystością mikrobiologiczną charakteryzowały się nasiona rzodkwi, natomiast nasiona słonecznika były najbardziej zasiedlone przez grzyby (tylko 26\% nasion czystych).

Tabela 2. Zasiedlenie nasion przeznaczonych na kiełki przez różne gatunki grzybów ocenione na pożywce PDA Table 2. Estimation of infection of seeds intended for sprout production by different kind of fungi using PDA medium

\begin{tabular}{|c|c|c|c|c|c|c|c|}
\hline \multirow{2}{*}{$\begin{array}{l}\text { Gatunek } \\
\text { Species }\end{array}$} & \multirow{2}{*}{$\begin{array}{l}\text { Nasiona czyste } \\
\text { Seeds free } \\
\text { of pathogens } \\
{[\%]}\end{array}$} & \multicolumn{6}{|c|}{$\begin{array}{c}\text { Procent nasion zasiedlonych przez różne patogeny } \\
\text { Percent seeds infested by different pathogens } \\
{[\%]}\end{array}$} \\
\hline & & $\begin{array}{l}\text { Penicillium } \\
\text { spp. }\end{array}$ & $\begin{array}{c}\text { Fusarium } \\
\text { spp. }\end{array}$ & $\begin{array}{l}\text { Mucor } \\
\text { spp. }\end{array}$ & $\begin{array}{c}\text { Alternaria } \\
\text { spp. }\end{array}$ & $\begin{array}{c}\text { Ulocladium } \\
\text { atrum }\end{array}$ & $\begin{array}{c}\text { Aspergillus } \\
\text { niger }\end{array}$ \\
\hline $\begin{array}{l}\text { Brokuł } \\
\text { Brocolli }\end{array}$ & 39 & 32 & 14 & 11 & 4 & - & - \\
\hline $\begin{array}{l}\text { Słonecznik } \\
\text { Sunflower }\end{array}$ & 26 & 38 & 8 & 19 & 4 & 5 & - \\
\hline $\begin{array}{l}\text { Rzodkiew } \\
\text { Radish }\end{array}$ & 56 & 19 & 16 & 4 & 5 & - & - \\
\hline $\begin{array}{l}\text { Fasola mung } \\
\text { Mung beans }\end{array}$ & 36 & 41 & 17 & 2 & 3 & - & 1 \\
\hline
\end{tabular}

Tabela 3. Zasiedlenie dostepnych w handlu kiełków przez różne gatunki grzybów ocenione na pożywce PDA Table 3. Sprout infection by different fungi species estimated on PDA medium

\begin{tabular}{l|c|c|c|c|c|c|c|c}
\hline \multirow{2}{*}{$\begin{array}{c}\text { Gatunek } \\
\text { Species }\end{array}$} & $\begin{array}{c}\text { Kiełki czyste } \\
\text { Sprouts free } \\
\text { of pathogens } \\
{[\%]}\end{array}$ & \multicolumn{7}{|c|}{$\begin{array}{c}\text { Procent kiełków zasiedlonych przez różne gatunki grzybów } \\
\text { Percent sprouts infected by different fungi species } \\
\text { [\%] }\end{array}$} \\
\cline { 3 - 9 } & $\begin{array}{c}\text { Penicillium } \\
\text { spp. }\end{array}$ & $\begin{array}{c}\text { Fusarium } \\
\text { spp. }\end{array}$ & $\begin{array}{c}\text { Mucor } \\
\text { spp. }\end{array}$ & $\begin{array}{c}\text { Alternaria } \\
\text { spp. }\end{array}$ & $\begin{array}{c}\text { Trichoderma } \\
\text { spp. }\end{array}$ & $\begin{array}{c}\text { Aspergillus } \\
\text { niger }\end{array}$ & $\begin{array}{c}\text { Colletotrichum } \\
\text { gleosporioides }\end{array}$ \\
\hline $\begin{array}{l}\text { Brokuł } \\
\text { Brocolli }\end{array}$ & 79 & 4 & - & - & 7 & 8 & 2 & - \\
\hline $\begin{array}{l}\text { Słonecznik } \\
\text { Sunflower }\end{array}$ & 19 & 10 & 3 & 30 & 26 & 12 & - & - \\
\hline $\begin{array}{l}\text { Rzodkiew } \\
\text { Radish }\end{array}$ & 72 & 7 & - & 5 & 8 & 5 & 2 & 1 \\
\hline $\begin{array}{l}\text { Fasola mung } \\
\text { Mung beans }\end{array}$ & 78 & 5 & - & 5 & 8 & 4 & - & - \\
\hline
\end{tabular}


Dostępne w handlu kiełki fasoli mung będące przedmiotem badań niniejszej pracy były zasiedlone przez grzyby m.in. z rodzajów Alternaria i Penicillium, natomiast nasiona przeznaczone na kiełki, były najliczniej zasiedlone przez grzyby z rodzaju Penicillium i incydentalnie przez Aspergillus spp. Obecność grzybów z rodzaju Penicillium nie wpłynęła jednak ani na energię ani na zdolność kiełkowania i nasiona fasoli mung kiełkowały najlepiej spośród nasion badanych gatunków roślin.

W podobnych, ale szerzej zakrojonych badaniach Rahman i wsp. (1999) ocenili zdrowotność nasion ośmiu odmian fasoli mung. Autorzy stwierdzili obecność grzybów z rodzaju Penicillium na wszystkich badanych odmianach. Na odmianie Chai Nat 60 grzyby te występowały w największej ilości. Autorzy w tym wypadku nie stwierdzili wpływu obecności Penicillium spp. na kiełkowanie nasion, co jest zgodne $\mathrm{z}$ obserwacjami przeprowadzonymi w badaniach własnych. Natomiast badanie innej odmiany fasoli mung, Chai Nat 36 dowiodły, że jest ona podatna na porażenie przez Alternaria spp., co niekorzystnie wpływa na kiełkowanie nasion.

Słonecznik w badaniach własnych charakteryzował się największym zasiedleniem nasion i kiełków przez grzyby oraz najmniejszą zdolnością kiełkowania w porównaniu z przebadanymi gatunkami roślin. Przeprowadzone analizy nasion i kiełków słonecznika wskazują, że zarówno gotowe do spożycia kiełki, jak i nasiona przeznaczone na kiełki były zasiedlone m.in. przez potencjalnie toksynotwórcze grzyby z rodzajów Fusarium i Alternaria.

Nahar i wsp. (2005) badając czystość mikrobiologiczną nasion słonecznika stwierdzili występowanie 45 gatunków grzybów. Zasiedlenie nasion przez gatunek Alternaria alternata w doświadczeniu było wysokie. Gatunek A. alternata zajmował piąte miejsce wśród 45 gatunków zidentyfikowanych na nasionach. Prasad i Singh (1983) donoszą, że obecność A. alternata na nasionach może prowadzić do obniżenia zdolności kiełkowania. Badania Tylkowskiej i wsp. (2003) także potwierdzają, że wysoka zawartość wtórnych metabolitów grzyba, tj. alternariolu i kwasu tenuazonowego bardzo niekorzystnie wpływa na proces kiełkowania.

Abdullah i Al-Mosawi (2010) badali zdrowotność dziewięciu różnych odmian słonecznika. Stwierdzili występowanie 48 różnych gatunków grzybów na nasionach. Grzyby, takie jak: A. alternata, F. oxysporum, Penicillium spp. i Ulocladium atrum występowały w największej ilości na trzech zakupionych, niezidentyfikowanych odmianach słonecznika. Wykazano, że właśnie te odmiany charakteryzowały się największym zasiedleniem oraz najmniejszą zdolnością kiełkowania w porównaniu $\mathrm{z}$ innymi odmianami.

W badaniach własnych zaobserwowano również liczne występowanie na nasionach i kiełkach słonecznika grzybów z rodzaju Mucor. Obecność tych grzybów może mieć wpływ na obniżenie kiełkowania nasion. Nie można jednak było wyciągnąć zbyt daleko idących wniosków w tym zakresie, ponieważ nasiona słonecznika generalnie kiełkowały najsłabiej i przyczyny tego mogą być różne.

Doświadczenie obejmowało również ocenę kiełkowania nasion oraz czystości mikrobiologicznej nasion i kiełków roślin kapustowatych, tj. rzodkwi i brokuła.
Nasiona brokuła kiełkowały znacznie lepiej, niż nasiona rzodkwi. W przeprowadzonych obserwacjach nie stwierdzono wpływu grzybów z rodzaju Alternaria na energię kiełkowania nasion brokuła. Możliwą przyczyną jest nisk procent porażenia nasion tego gatunku. Rude i wsp. (1999) prowadząc bardziej zaawansowane badania stwierdził, że występowanie grzybów Alternaria spp. na nasionach Brassica rapa L. wpływa na obniżenie zdolności kiełkowania.

Niepokojącym wydaje się stwierdzenie na nasionach i kiełkach grzybów zdolnych do biosyntetyzowania szkodliwych metabolitów. Wśród licznie występujących na nasionach potencjalnie toksynotwórczych grzybów na szczególną uwagę zasługują te, które należą do rodzajów Alternaria, Fusarium i Penicillium. Przy bardzo dużym stężeniu mykotoksyn w często spożywanej żywności, u konsumentów może dojść do uszkodzenia narządów wewnętrznych, co w konsekwencji może być przyczyną różnorodnych chorób. Jeżeli natomiast przy regularnej konsumpcji skażonej żywności stężenie toksyn jest niskie, z czasem dochodzi do kumulatywnego oddziaływania na organizm człowieka, a po kilku latach może skutkować rozwojem przewlekłych chorób, w tym także nowotworowych (Pokrzywa i wsp. 2007).

Występujące na nasionach i kiełkach grzyby z rodzaju Alternaria stanowią bardzo zróżnicowaną grupę pod względem morfologicznym i biologicznym. Niektóre gatunki z tego rodzaju biosyntetyzują mykotoksyny, między innymi, takie jak: alternariol, kwas L-tenuazonowy, altertoksyny I, II, III (Ogórek i wsp. 2011). Donoszono o występowaniu mykotoksyn produkowanych przez Alternaria sp. w nasionach słonecznika i rzepaku (Ito i wsp. 2004).

W przypadku kontaktu z A. alternata i innymi, łatwo zarodnikującymi grzybami zaobserwowano u ludzi reakcje alergiczne. Uczulają głównie zarodniki niewielkich rozmiarów, które mogą przenikać do drzewa oskrzelowego, a w konsekwencji wywołać astmę. Uważa się, iż alergeny zarodników A. alternata uwalniane są z łatwością i są powszechnie występującymi aeroalergenami (Lipiec 2002).

Występujące na badanych nasionach grzyby należące do rodzaju Fusarium również biosyntetyzują mykotoksyny. Spożywanie produktów zanieczyszczonych mykotoksynami grzybów, takich jak: $F$. oxysporum oraz $F$. proliferatum, czyli moniliforminą lub fumonizynami może prowadzić do obrzęku płuc, raka krtani, nowotworów wątroby, a także uszkodzeń mózgu (Waśkiewicz i wsp. 2013).

Zanieczyszczenie toksynami nasion i ich produktów stanowi duży problem dla ogrodnictwa i rolnictwa. Fumonizyny, zearalenon i deoksynivalenol produkowane przez Fusarium mogą kumulować się w produktach zbożowych. Spożywanie skażonych produktów prowadzi do zaburzeń hormonalnych i innych poważnych schorzeń (Korbas i Horoszkiewicz-Janka 2013).

Nicholson (2004) stwierdził, że skażenie żywności fumonizyną $B_{1}$ miało wpływ na występowanie raka przełyku u ludzi zamieszkujących Stany Zjednoczone, Afrykę i Chiny. Międzynarodowa Agencja Badań nad Rakiem (IARC - International Agency for Research on 
Cancer) uznała $\mathrm{FB}_{1}$ za toksynę o działaniu kancerogennym u ludzi (Irzykowska i wsp. 2012).

Wyniki badań wskazują, że ani spożywanie gotowych, dostępnych w handlu kiełków ani ich samodzielna produkcja, nie chronią konsumentów przed negatywnym wpływem zasiedlających je grzybów i ich metabolitów, przy czym nasiona przeznaczone na kiełki były bardziej skażone niż kiełki gotowe. Jeżeli dalsze badania potwierdzą, że w kiełkach obecne są nie tylko grzyby, ale też mikotoksyny, to potencjalne korzyści dla zdrowia płynące ze spożywania kiełków zostaną drastycznie obniżone.

\section{Wnioski / Conclusions}

1. Badane nasiona fasoli mung i brokuła kiełkowały równomiernie w czasie zgodnym $\mathrm{z}$ informacją zamieszczoną przez producenta na etykiecie. W przypadku nasion rzodkwi i słonecznika zdolność i energia kiełkowania istotnie odbiegały od wartości oczekiwanych.

2. Zarówno badane nasiona, jak i gotowe kiełki były znacznie zasiedlone przez niepożądane grzyby.
3. W przypadku gotowych, dostępnych w handlu kiełków brokuła, rzodkwi i fasoli mung około $80 \%$ było wolne od patogenów.

4. Badane nasiona i gotowe kiełki słonecznika odznaczały się największym zasiedleniem przez grzyby. Występowanie tych szkodliwych mikroorganizmów mogło mieć istotny wpływ na obniżenie zdolności kiełkowania.

5. Obecność grzybów w produkcie, który ma wzbogacać dietę powinna być brana pod uwagę przez alergików. Część z wyizolowanych z nasion i kiełków grzybów może być toksynotwórcza.

6. Wyniki wskazują, że bezpieczniej jest wzbogacać swoją dietę gotowymi, dostępnymi w handlu kiełkami niż hodować je z nasion samodzielnie. Jednak przed sformułowaniem daleko idących wniosków konieczne byłoby zbadanie większych partii nasion i kiełków pod kątem obecności w nich patogenów, ich mykotoksyn i ewentualnych pozostałości substancji chemicznych stosowanych w celu zahamowania rozwoju niepożądanej mikroflory.

7. Biorąc po uwagę znaczne zanieczyszczenie mikrobiologiczne nasion przeznaczonych na kiełki (w przypadku słonecznika aż 80\%) zasadne wydaje się zwiększenie kontroli ich czystości.

\section{Literatura / References}

Abdullah S., Al-Mosawi K. 2010. Fungi associated with seeds of sunflower (Helianthus annuus) cultivars grown in Iraq. Phytopathologia 57: 11-20.

Duczmal K.W. 1993. Nasiennictwo ogrodnicze. Wydawnictwo Akademii Rolniczej w Poznaniu, 195 ss.

Gawlik-Dziki U., Kowalczyk D. 2007. Wpływ warunków ekstrakcji na aktywność przeciwutleniającą ekstraktów z kiełków rzodkiewki. Żywność. Nauka. Technologia. Jakość 1 (50): 132-139.

Irzykowska L., Bocianowski J., Waśkiewicz A., Weber Z., Karolewski Z., Goliński P., Kostecki M., Irzykowski W. 2012. Genetic variation of Fusarium oxysporum isolated forming fumonisin $B_{1}$ and moniliformin. Journal of Applied Genetics 53 (2): $237-247$.

ISTA 2003. International Rules for Seed Testing. ISTA, Basserdorf, Switzerland.

Ito K., Tanaka T., Hatta R., Yamamoto M., Akimitsu K., Tsuge T. 2004. Dissection of the host range of the fungal plant pathogen Alternaria alternata by modification of secondary metabolism. Molecular Microbiology 52 (2): 399-411.

Korbas M., Horoszkiewicz-Janka J. (red.). 2013. Zapobieganie powstawaniu mikotoksyn - rośliny rolnicze. Ekspertyza. Instytut Ochrony Roślin - Państwowy Instytut Badawczy, Poznań, 11 ss.

Laemmlen F. 2001. Alternaria diseases. University of California, Agriculture and Natural Resources Publication 8040, 5 pp.

Lewicki P. 2010. Kiełki nasion jako źródło cennych składników odżywczych. Żywność. Nauka. Technologia. Jakość 6 (73): 18-33.

Lipiec A. 2002. Grzyby w etiologii chorób alergicznych. Alergologia Współczesna 10: 10-14.

Nahar S., Mushtaq M., Nashmi M.H. 2005. Seed-borne mycoflora of sunflower (Helianthus annuus L.). Pakistan Journal of Botany 37 (2): 451-457.

Nicholson P. 2004. Rapid detection of mycotoxigenic fungi in plants. p. 111-152. In: "Mycotoxins in Food: Detection and Control” (N. Magan, M. Olsen, eds.). Woodhead Publishing Cambridge, 471 pp.

Ogórek R., Pląskowska E., Kalinowska K. 2011. Charakterystyka i taksonomia grzybów z rodzaju Alternaria. Mikologia lekarska 18 (3): 150-155.

Pokrzywa P., Cieślik E., Topolska K. 2007. Ocena zawartości mikotoksyn w wybranych produktach spożywczych. Żywność. Nauka. Technologia. Jakość 3 (52): 139-146.

Prasad T., Singh B. 1983. Effect of relative humidity on oil properties of fungal infested sunflower seeds. Biology Bulletin India 5: 85-88.

Rahman S., Vearasilp S., Srichuwong S. 1999. Detection of seed-borne in mungbean and blackgram seeds. Deutscher Tropentag 1999 in Berlin Session: Sustainable Technology Development in Crop Production: 1-3.

Rude S.V., Duczek L.J., Seiale E. 1999. The ffect of Alternaria brassicae, Alternaria raphani and Alternaria alternata on seed germination of Brassica rapa canola. Seed Science Technology 27: 795-798.

Świeca M., Gawlik-Dziki U., Dziki D., Baraniak B. 2012. Kiełki brokułu jako źródło potencjalnie bioprzyswajalnych antyoksydantów. Bromatologia i Chemia Toksykologiczna 45 (3): 488-493.

Tylkowska K., Grabarkiewicz-Szczęsna J., Iwanowska H. 2003. Production of toxins by Alternaria alternata and A. radicina and their effect on germination of carrot seeds. Seed Science and Technology 31 (2): 309-316.

Waśkiewicz A., Irzykowska L., Bocianowski J., Karolewski Z., Weber Z., Goliński P. 2013. Fusariotoxins in asparagus - their biosynthesis and migration. Food Additives and Contaminants, Part A 30 (7): 1332-1338. DOI: 10.1080/19440049.2013.796095. 